\title{
LO FEMENINO EN LA ESCRITURA DE LEZAMA LIMA
}

\author{
Armando LÓPEZ CASTRO \\ Universidad de León \\ alopc@unileon.es
}

$\mathrm{E}$ n una carta a su hermana Eloísa, fechada en La Habana, el 10 de mayo de 1965, el escritor cubano José Lezama Lima, refiriéndose a la reciente pérdida de su madre, escribe: «Así nos enseñó también la religiosidad por el sacrificio. Como lo sacrificó todo, todo le fue otorgado». Esta vinculación de la mujer con el sacrificio, acto ritual de dispersión y reunión, le da un carácter sagrado, propio de las llamadas 'religiones del origen', las cuales, frente a las 'religiones de la salvación o de la redención', insertas en el tiempo lineal de la Historia, se caracterizan por el ritmo circular de la Naturaleza, orientado fundamentalmente a la generación y la fecundidad. Para Lezama, la mujer siempre está más allá de la Historia, deteniendo el tiempo y haciéndolo empezar de nuevo, de ahí que su cuerpo se convierta en expresión de la alteridad absoluta y su matriz vaya ligada a la escritura del mundo, que se compone de urdimbre y trama. En la medida en que la matriz de una escritura puede albergar distintas voces, el sexo femenino, en su espera pasiva, se remonta hasta el nacimiento mismo del verbo, de la realidad que busca expresarse ${ }^{1}$.

La unión de lo dual, recuerdo de la primera pareja, corresponde por naturaleza al Eros, cuyo movimiento consiste en ir hacia lo que aún no es, hacia lo que se ha de engendrar. Esta ambigüedad constitutiva de lo erótico, que oscila entre el más acá de la necesidad y el más allá del deseo, se percibe ya en las composiciones de la primera etapa, formada por el poema Muerte de Narciso (1937) y el libro Enemigo rumor (1941), en donde la voz poética procede de su propio impulso interior y se configura por la fuerza de su ruptura, como estallido de un parto. Esta irrupción reveladora aparece en el primero de los «Sonetos a la Virgen», donde la figura de María, mediadora entre lo humano y lo divino, se muestra en su función material, inscrita en el tiempo de la fecundidad, donde lo continuo se hace eterno:

Deípara, paridora de Dios. Suave

la giba del engañado para ser

tuvo que aislar el trigo del ave,

\footnotetext{
${ }^{1}$ Aludiendo a la ausencia amorosa, que es ausencia del otro, señala Barthes: «Se sigue de ello que en todo hombre que dice la ausencia del otro, lo femenino se declara» (1982: 46). En cuanto a la distinción entre las 'religiones de la naturaleza' y las 'religiones de la salvación', remito al estudio de Schubart (1966).
} 
el ave de la flor, no ser del querer.

5 El molino, Deípara, sea el que acabe la malacrianza del ser que es el romper. Retuércese la sombra, nadie alabe la fealdad, giba o millón de su poder.

Oye: tú no quieres crear sin ser medida.

10 Inmóvil, dormida y despertada, oíste espiga y sistro, el ángel que sonaba.

La nieve en el bosque extendida. Eternidad en el costado sentiste Pues dormías la estrella que gritaba.

La mujer ama desde el fondo y tiene un lenguaje aparte. El hecho de que la Virgen aparezca aquí como «Deípara» o madre de Dios, título que la Iglesia cristiana primitiva dio a María en el Concilio de Éfeso, del año 431, y no como intercesora de los hombres ante Dios, pensamiento dominante a lo largo de la Edad Media, de acuerdo con los escritos de san Bernardo, el cantor de la Virgen, no hace más que subrayar la asociación de María con el Verbo encarnado, de la teología con la poesía, pues si por algo se distingue la palabra poética es por su enorme poder de encarnación. En este sentido, los recursos expresivos más destacados en el poema, como el uso del lenguaje apelativo, visible en la presencia del vocativo («Deípara»), y del imperativo («Oye»), que indican una experiencia compartida; la frecuencia de versos encabalgados ( «Suave / la giba del engañado para ser», «sea el que acabe / la malacrianza del ser que es el romper», «nadie alabe / la fealdad», «oíste / espiga y sistro»), cuya flexibilidad rítmica consigue una agilidad muy notable del discurso; y de símbolos reiterados a lo largo del conjunto, como «la nieve», ligada al hallazgo, y «la estrella», evocadora de lo alto, inciden todos ellos en la naturaleza misma del proceso creador, que tiene como fin revelar lo esencial que está oculto bajo las apariencias. Ese mundo femenino es un fondo de sombra que la palabra explora y hace estallar («Retuércese la sombra»), dispuesto a recibir el germen de la palabra, acto generador por excelencia. El que lo erótico vaya aquí ligado a lo poético, experiencia que se reitera una y otra vez en la escritura de Lezama, muestra la condición ambigua de la mujer, cuya oscura gestación, reino de lo virginal, se resiste a ser expresada y hace que el rumor sea capaz de conjurar la distinción, de engendrar lo posible ${ }^{2}$.

Si el lenguaje de Enemigo rumor revela una polaridad complementaria de lo erótico y de lo poético, en los libros de la segunda etapa, Aventuras sigilosas (1945), La fijeza (1949) y Dador (1960), hay una renuncia a la causalidad para centrarse en lo que es propiamente germinativo o creador, en un conocimiento de la realidad por la imagen. Tal conocimiento da paso a lo incondicionado, al que se llega después del viaje catártico que tiene lugar a lo largo de Aventuras sigilosas, destinado a proyectar

\footnotetext{
${ }^{2}$ La condición equívoca de la poesía, que mantiene una analogía con lo erótico, es ajena a cualquier forma de intencionalidad o posesión («Nada se aleja más del Eros que la posesión», afirma Lévinas en Totalidad e Infinito). En cuanto a la función reveladora de la palabra poética, presente a lo largo del libro, véase el ensayo de Ruiz Barrionuevo (1984: 171-186).
} 
lo humano al plano de la creación poética, ante la inminencia de la muerte. En esa espera de lo incondicionado, inherente a la naturaleza misma de la escritura poética, se sitúa el poema «La esposa en la balanza», donde el símbolo de la balanza, que ya aparece en el Libro de los muertos para pesar las almas, corresponde al medio invariable y sirve para equilibrar lo exterior y lo interior, lo natural y lo espiritual:

\section{LA ESPOSA EN LA BALANZA}

La siembra del violín o de la hoja, no la punta del cono hacia dentro de la sangre azucarada; un deseo en la baba del caracol que afeita en nuestros sentidos toda la transmutación

5 del rostro en el círculo de cobre que no gira. Ese afán tan del pecho no balanceado, sino fijo como un pellejo de vino, de recorrer cabellos, de seguir el hilo de bocado ajeno.

Oh, mi mano que vas impulsando el río,

10 te detienes en los pechos y allí quieres soplar, no en un tren ni en un barco, en los techos caídos por un agua arrastrada.

De ese arrastre en que el río pesa más que la casa y más que el fuego cuando se dirige al dosel del estrado.

15 Pero salimos con dos pares de bueyes y los bueyes suenan en la canal del arco iris. Pero salimos también con nuestra sustancia malgastada, filtrándose por lo que mira como el ramaje cuando le toca un pájaro rodado en una muerte oblicua.

20 La muerte oblicua es tirar del ramaje. La recta va en un túnel regalando manzanas. Sabe llegar, no como un gimnasta que se despide, sino como el que lleva sus manos en un saco de mármol ablandado. Fluye como el fuego cuando el noroeste lo sopla,

25 va del manglar a la tortuga quemada, pero sus dos ojos tesoneros como una garra melancólica. Después de todo es una flor y así también es una flor. Así también es una flor en la boca del esturión carnavalesco. Después de todo el pez y su flor tienen que ir a la balanza.

30 Tampoco duerme en la balanza el hombre recamado de consejos.

Tiene una espuma oscura que le llena la nube en cuclillas que sale de su boca.

La poesía, siendo contraria a la apariencia, busca la realidad oculta. En el fragmento XVIII, decía Heráclito: «Si uno no espera lo inesperado nunca lo encontrará, pues es imposible de encontrar e impenetrable». En la misma órbita se sitúa Lezama, ya que lo inesperado es aquí la muerte, lo otro absoluto, que al sobrepasarnos y no poder expresarla de forma directa, sino oblicua («La muerte oblicua es tirar del ramaje»), requiere un reconocimiento de la realidad. En efecto, todo el poema gira sobre ese verso nuclear, a partir del cual se organizan los recursos expresivos: la marca subjetiva de la exclamación («Oh, mi mano que vas impulsando el río»), que subraya la actitud del hablante; el río como imagen de la vida humana en su discurrir hacia la muerte («De ese arrastre en que el río pesa más que la casa»), de acuerdo con la vieja tradición manriqueña; y sobre todo, el símbolo de «la balanza», que da título al poema y que, al final, aparece como síntesis unificadora («Después de todo el pez y la flor tienen que ir a la balanza»), donde se funden lo abismático y lo superficial, lo masculino 
y lo femenino, ya que lo propio de la poesía es reducir lo dual a lo único. Ahora bien, si la palabra poética es una forma de resistencia contra el olvido, ligado a la pérdida, lo que hace la «vivencia oblicua», aplicada a la muerte, es romper la causalidad e introducir lo incondicionado en la escritura. Si resulta imposible dar un nombre a la muerte, ya que toda muerte es amor, lo que hace el deseo, en su potencialidad insatisfecha («un deseo en la baba del caracol», «Ese afán tan del pecho no balanceado»), pues el poema transcurre en el plano de lo ideal, es convertir a esa protagonista en muerta-viviente. Dentro de un poemario como Aventuras sigilosas, donde se funden la madre, la esposa y el hijo, lo que hace la muerte es intercambiar sexos e identidades, presentarse como lo incondicionado que fluye y nada puede detener («Fluye como el fuego cuando el noroeste lo sopla»), que escapa a toda presencia y tiene fuerza creadora, Lo que busca la escritura es decir lo ausente, lo que está al otro lado, detrás del «ramaje», lo invisible como último estado de lo visible ${ }^{3}$.

El abandono de lo causal y la apuesta por lo germinativo se entrelazan en la escritura expansiva de Dador (1960), que empieza por un ballet y termina en un danzón, desplazándose espiralmente, a través de nueve círculos o vueltas, hasta el límite de lo imposible, que es también el objeto de toda poesía. Entre ambos extremos aparece un texto múltiple y remoto, 'dador de sentido', cuya dimensión religiosa, en contacto con la fuerza latente de lo numinoso, ha de ser interpretada simbólicamente como un oscuro reconocimiento de lo desconocido. Todo lo dicho en el poema, recuerdo de una pérdida, apunta siempre a un más allá de sí mismo, pues lo que hace el símbolo es trasladar lo inmediato a la esfera de lo trascendente. En este sentido, considerando a Dador como objeto simbólico, ajeno al orden referencial, lo erótico se percibe como experiencia relacionable en la tensión de la diferencia. Lezama creyó en la posibilidad de convertir lo erótico en poético y así lo expresa en este fragmento perteneciente al extenso poema que abre el libro y lleva su mismo título:

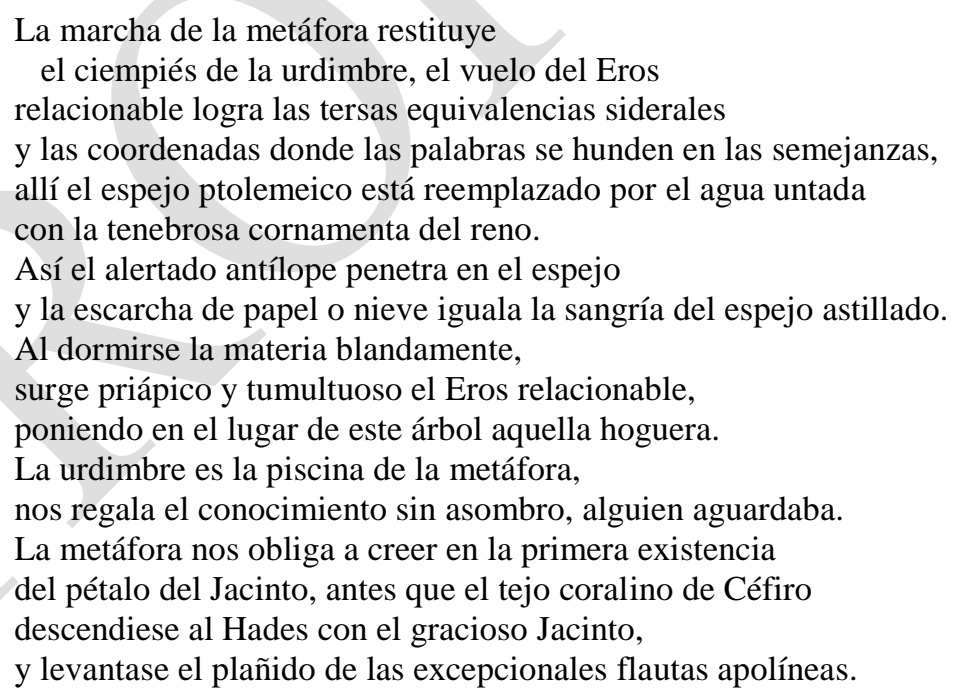

\footnotetext{
${ }^{3}$ En el texto «Las imágenes posibles», contemporáneo de Aventuras sigilosas, pues data de 1948 y fue incluido en Analecta del reloj (1953), señala Lezama: «Entre la carta oscura entregada por la metáfora, precisa sobre sí y misteriosa en sus decisiones asociativas y el reconocimiento de la imagen, se cumple la vivencia oblicua» (1975-1977: 158). En esta misma línea, véase el ensayo de Valcárcel (1999: 1255-1263).
} 
La experiencia erótica y la experiencia poética, desunidas y unidas en la escritura, tienen su origen común en el principio universal de la semejanza, a través del cual llegamos a calar en la identidad («¿Podrá reaparecer lo semejante primigenio?», se pregunta el hablante en el poema «Recuerdo de lo semejante», de este mismo libro). La forma de penetrar en esta realidad trascendente es la metáfora, entendida, en su sentido sagrado, como mediadora entre este mundo y el otro, como forma de restituir la unidad arquetípica del origen («La marcha de la metáfora restituye / el ciempiés de la urdimbre»). A partir de esa 'restitución', que apunta al tejido mismo de la escritura, se entiende el concepto de «Eros relacionable», sintagma repetido en el fragmento y que hace referencia al estado germinativo de la indistinción primordial, en donde se anulan los opuestos y lo causal se intercambia con lo incondicionado. Agente de toda trascendencia, lo erótico necesita de la progresión de la metáfora y de la continuidad de la imagen para convertir, por medio de la semejanza, lo irreal en posibilidad creíble, como si lo invisible fuese escritura a la espera («alguien aguarda»). De ahí que los signos expresivos del fragmento, como el valor cualitativo de los adjetivos antepuestos («tersas equivalencias siderales», «tenebrosa cornamenta del reno», «el alertado antílope», «priápico y tumultuoso el Eros relacionable», «la primera existencia», «el gracioso Jacinto», «las excepcionales flautas apolíneas»); el símbolo del espejo roto («la sangría del espejo astillado»), que revela el reconocimiento de la identidad perdida; y las resonancias mitológicas, sobre todo la muerte de Jacinto, transformado por Apolo en la flor que lleva su nombre, vayan todos ellos en función de esa suspensión que se da tanto en el amor como en la poesía. Porque si escribir es hacerse semejante a la palabra inicial, lo erótico se configura como base de la expresión verbal. Para Lezama, lo erótico y lo poético convergen en la reducción de lo dual a lo único, en el reconocimiento de la unidad perdida, pues lo sexual es acorde o armonía con el punto primigenio de la creación ${ }^{4}$.

La vigencia de un universo poético depende tanto de la solidez de su estructura como de la capacidad de la imagen para establecer una relación entre lo inmediato y lo trascendente. El propio Lezama, al hablar de Paradiso (1966), señala: «Creo que mi novela tiene los tres temas que pueden interesarle más al hombre: la madre, la amistad y la infinitud». En realidad, los tres se inscriben en el territorio ambiguo de lo femenino, donde la mujer aparece en su radical alteridad y el lenguaje se revela con la fuerza de lo ausente, de lo que está más allá de lo posible y todavía no se ha manifestado. En su función materna de la fecundidad, la mujer incluye una dualidad de lo idéntico, que desarticula lo histórico y nos devuelve a la unidad del origen, a lo que vuelve a empezar infinitamente. Lo fecundo no se opone a lo múltiple, sino que lo engendra a partir de su impulso de conocimiento, que corresponde por naturaleza al Eros. De ahí que, en la escritura de Paradiso, que surge como intento de llenar una ausencia, la del padre muerto, la mujer ocupe un papel central, más como madre que como amiga o hermana, y contribuya, con su creación inagotable, al ritmo integrador de la poesía. Sin la ternura de Rialta, que funciona esencialmente como madre, no podría entenderse el personaje de Cemí,

\footnotetext{
${ }^{4}$ En cuanto a la penetración en el territorio de lo sagrado mediante la metáfora, afirma Murena: «El arte, al mostrarnos el Otro Mundo mediante la inspirada manipulación de elementos de este mundo, nos muestra la posibilidad de vivir nuestra vida en aquello en que es otra, la posibilidad de vivirla esencialmente según la esencia de la poesía, como una metáfora» (1984: 27). Sobre el concepto de «Eros relacionable», remito al ensayo de Yurkievich (2002: 407-425).
} 
obsesionado por la búsqueda de lo desconocido a través de la poesía, y al que Rialta dice en el capítulo IX de la novela:

El paso de cada cuenta del rosario, era el ruego de que una voluntad secreta te acompañase a lo largo de la vida, que siguieses un punto, una palabra, que tuvieses siempre una obsesión que te llevase siempre a buscar lo que se manifiesta y lo que se oculta. Una obsesión que nunca destruyese las cosas, que buscase en lo manifestado lo oculto, en lo secreto lo que asciende para que la luz lo configure. Eso es lo que siempre pido para ti y lo seguiré pidiendo mientras mis dedos puedan recorrer las cuentas de un rosario.

Si tenemos en cuenta que estas palabras de Rialta surgen para llenar la ausencia del padre muerto y aparecen en el período de la adolescencia de Cemí, comprendemos que esa voluntad de buscar «en lo manifestado lo oculto, en lo secreto lo que asciende para que la luz lo configure», además de poner de relieve una estética de procedencia órfica, que consiste en adentrarse en lo misterioso para ir hacia lo infinito posible, ofrece una transfiguración de la realidad que apunta a una reconciliación, según vemos en el sueño de Cemí, donde el pez se transmuta en la madre y su armonía despierta la transparencia de la Naturaleza. En esa experiencia de la totalidad, encarnada por la madre y que aparece como el fundamento de la novela, convergen lo erótico y lo poético, que suspenden toda dualidad y aspiran a la unidad del origen. En la indistinción de lo erótico, que no conoce diferencia de sexo, se refleja el estado de identidad, previo a la creación, el punto límite entre lo no manifestado y lo manifestado, lo incondicionado de la escritura poética, capaz de fundir nuestra relación con el mundo. Aligerada del peso de toda condición, la escritura de Paradiso busca redimir la luz en la sombra, mostrando un apasionado fervor por la primigenia, con su «existir fulgurante», aspira a rescatar la naturaleza perdida 5 .

La fusión de prosa y poesía en la escritura de Paradiso, que constituye uno de sus mayores atractivos, se prolonga en la de Oppiano Licario (1977), que es una novela inacabada, incompleta en su infinitud, donde la reactualización del pasado da lugar a una búsqueda de lo nuevo. Desde el punto de vista erótico, mientras en Paradiso el Eros actúa como impulso germinativo, en Oppiano Licario aparece como unión cósmica de los contrarios, haciendo que la lejanía de lo erótico se materialice en la proximidad del cuerpo y la imagen se convierta en una visión trascendental del mundo, según vemos en el episodio de las relaciones entre Ynaca Eco y José Cemí, marcadas por el deseo que tienen los cuerpos de fundirse, por una relación simpatética con el ritmo del universo, que es tanto erótica como verbal («El simphatos, el Eros de la lejanía irradiando en el cuerpo que estaba a su lado», capítulo V),y que tiene una continuidad más intensa en el encuentro de Ynaca con Fronesis dentro del capítulo VII de la novela:

La desnudez de Ynaca le producía a Fronesis todo lo contrario de lo que había sentido frente al cuerpo de Lucía. Sentía que en Ynaca se continuaba, no la interrupción espacial de los dos cuerpos, sino como una transparencia extendida y acariciada. En ese instante sentía también su sucesión con los árboles y el río, con

\footnotetext{
${ }^{5}$ Refiriéndose a la analogía de lo erótico y lo poético, afirma Bataille: «La poesía conduce al mismo punto que cada forma del erotismo, a la indistinción, a la confusión de los objetos distintos» (1982: 40). En cuanto a la presencia de la madre en la aventura de Cemí, señala Ortega: «La madre es el punto de partida, la forma manifestada, de una forma no manifestada, por conquistar, ligada al padre. Y el hogar todo viene a ser el permanente fondo, la tierra fértil, de esa aventura» (1969: 103).
} 
las columnas y sus reflejos. Nada interrumpía, nada irrumpía, nada prorrumpía. Su piel no era el límite de su cuerpo, sino la sucesión infinita en la piel de otro cuerpo, en la llanura, en la corteza de los árboles, en la fluencia del río. No pudo precisar si su posesión de Ynaca había sido horizontal o vertical, acostados en el sueño o en una danza ascendente. Tampoco pudo precisar el comienzo de la dicha o la extenuación final. Los dos cuerpos caminaron hasta el río, pero algo invisible de ellos que allí se había quedado comenzaba de nuevo la medianoche de las bodas.

El cuerpo se configura como hecho presente de lo ausente. En la escritura de Lezama, que tiene su lugar sobre el límite, no se escribe acerca del cuerpo, de su gravedad o extrañeza, sino que es el cuerpo el que escribe, el que toca el extremo de lo posible. Por eso, el cuerpo de Ynaca se ofrece a Fronesis expuesto en su desnudez, atributo de lo sagrado, como si fuese el texto mismo abandonado, dejado sobre su límite. Y como el cuerpo es el lugar de un acontecimiento, puesto que está aquí, hace falta escribir desde ese cuerpo, desde su borde o contorno, que nos lleva a traspasar el límite, que nos expone a la totalidad del sentido. De ahí que los recursos más visibles de este fragmento, como el predominio de la forma verbal en imperfecto de indicativo ( «Nada interrumpía, nada irrumpía, nada prorrumpía»), tiempo de la evocación; la reiteración de unas semejantes estructuras sintácticas, dependientes de un mismo núcleo verbal («No pudo precisar»), que inciden sobre una misma indeterminación, propia de lo poético; y las imágenes del «río», como fluir de la vida, y «la medianoche de las bodas», como visión mística de unión espiritual, vayan todos ellos en función de esa continuidad que se quiere transmitir. Porque los cuerpos están en el aquí y ahora del poema para exponer un pensamiento, el de la unidad perdida desde la separación, la promesa abierta a una presencia que no ha tenido lugar. Si el cuerpo del amor se relaciona con el de la palabra por su capacidad de encarnación, lo que hace el lenguaje, en tanto que cuerpo, es reunir lo sensible y lo inteligible en esa reabsorción circular del cuerpo femenino. Partiendo de que el cuerpo es la carne viva del espíritu, lo que deja ver la exposición de su desnudamiento es lo que está en otra parte o viene súbitamente de otro lado en la escritura, la irrupción de lo que se desconoce en una sola imagen visible de lo invisible. De este modo, la verdad del cuerpo se halla en su exposición, en tener un lugar para que lo otro pueda ser revelado ${ }^{6}$.

¿Qué sería de la totalidad sin el fragmento que sin cesar remite a ella? Según escribió Poe, los géneros breves, como el aforismo, la greguería, el fragmento o el haiku, son propios de la época moderna y determinan un cambio de mentalidad. En cuanto al fragmento, hay que tener en cuenta que la obra de arte, resto de un trato con lo absoluto, es por esencia fragmentaria. Para Lezama, el fragmento estaría en la línea de Baudelaire, que define a los fragmentos como «los testimonios nupciales de la idea», definición que ya está en Novalis, en sus Fragmentos tan llenos de ciencia y poesía, y que después se repite en la poesía de Mallarmé, Valéry, hasta llegar a Eliot, que finaliza así La tierra baldía: «Con estos fragmentos he apuntalado mis ruinas». Por aludir a un mundo sumergido, el fragmento remite a un más adentro de sí mismo, es como una llave que nos invita a entrar en el fondo de la experiencia oculta. Brevedad, concentración y sugerencia son los rasgos propios del

\footnotetext{
${ }^{6}$ Aludiendo a la exposición del cuerpo como extensión, escribe Nancy: «Todo el asunto está ahí: un cuerpo corresponde a la extensión. Un cuerpo corresponde a la exposición. No sólo que un cuerpo es expuesto, sino que un cuerpo consiste en exponerse» (2003: 95). En cuanto a la «convergencia de modelos» en la escritura de Oppiano Licario, remito al ensayo de Matamoro (1987: 197-212).
} 
fragmento, los que hacen que la emoción brote directa y espontánea. Tales rasgos se reconocen en la escritura de Fragmentos a su imán (1977), en donde el centro último, dotado de atracción, reúne los fragmentos dispersos y los lleva a la respiración de su condición primera, como si la imaginación, en su estado naciente, fuese capaz de alcanzar por fin la transparencia. Desde el punto de vista erótico, hay poemas claves de este centro inmóvil, donde el conocimiento, que aparece como fruto del sentir iluminante, se alcanza directamente, sin mediación alguna, como «La madre», «Eloísa Lezama Lima», «Mi esposa María Luisa» y «La mujer y la casa», pero si tuviera que destacar uno de ellos, me quedaría con este último, fechado en 1976, donde la mujer aparece como centro de la vida familiar:

\section{LA MUJER Y LA CASA}

\section{Hervías la leche}

y seguías las aromosas costumbres del café.

Recorrías la casa

con una medida sin desperdicios.

5 Cada minucia un sacramento, como una ofrenda al peso de la noche.

Todas tus horas están justificadas

al pasar del comedor a la sala, donde están los retratos

10 que gustan de tus comentarios. Fijas la ley de todos los días y el ave dominical se entreabre con los colores del fuego y las espumas del puchero.

15 Cuando se rompe un vaso, es tu risa la que tintinea.

El centro de la casa vuela como el punto en la línea. En tus pesadillas

20 llueve interminablemente sobre la colección de matas y el flamboyán subterráneo. Si te atolondraras, el firmamento roto

25 en lanzas de mármol, se echaría sobre nosotros.

El poeta habla en el límite del lenguaje y sus imágenes son destellos, revelaciones súbitas, de lo que se forma en su interior. Decir, por ejemplo, que la casa es una imagen del cosmos no sólo implica un espacio realmente habitado, sino también una dialéctica entre lo interior y lo exterior, entre lo cerrado y lo abierto. Si además la madre y la esposa se confunden en la mujer que habita ese espacio íntimo, que aparece como centro de la vida familiar, se entenderá mejor esa morada de inmensidad que la poesía pretende hacer eterna. Por eso, todo el poema gira en torno a ese núcleo de vida interior ( «El centro de la casa / vuela como el punto en la línea»), capaz de concentrar por sí mismo todos los recuerdos vividos. Dentro del ámbito onírico en que transcurre el poema («En tus pesadillas»), las imágenes de «los retratos» familiares, «el ave dominical» $\mathrm{y}$ «el vaso roto», repetida al final en «el firmamento roto», reproducen las huellas de esa casa perdida en la memoria, que es por naturaleza selectiva y fragmentaria. En el recinto tenue del recuerdo hay que encontrar de nuevo, mediante el 
vuelo de la imaginación, la luz de la casa que se abre desde la noche acogedora que la envuelve. Tal vez por eso, la humanidad que irradia esa casa sólo se percibe a través del sacrificio de esa mujer, de su condición abnegada y servicial («como una ofrenda al peso de la noche»), pues es propio del sacrificio reunir lo disperso, dar testimonio de una experiencia compartida. Al mismo tiempo, en esa casa convergen dos niveles complementarios, lo gravitante y lo aéreo, la concentración y la expansión, que se integran en el ritmo único de la poesía. La imagen que Lezama tiene del mundo, que se forma y renueva desde la intimidad, recibe todo su poder mágico de la imaginación, de lo sombrío que sube a la luz, pues lo femenino sólo se entiende a partir de lo oscuro que engendra la creación ${ }^{7}$.

La tradición afrocubana, la que se ha conocido como «Negrismo» a partir de 1930, que está presente en escritores como Nicolás Guillén, Emilio Ballagas, Lydia Cabrera o Alejo Carpentier, y pensadores como Fernando Ortiz, es un componente básico de la cultura cubana. Lezama Lima la tuvo en cuenta en el relato «Cangrejos, golondrinas», publicado en Orígenes, 1946, que transcurre en un ambiente de magia y santería, donde las prácticas rituales y los conjuros contribuye al logro de la seducción amorosa. De entrada, hay que señalar que los cuentos de Lezama no son episodios marginales en su evolución, sino que se presentan a lo largo de su escritura, desde «Fugados», publicado en Grafos, 1936, hasta «Para un final presto», publicado póstumamente en 1984, pasando por «Juego de las decapitaciones», tal vez el más consistente y elaborado, anticipan y contienen en germen el conocido problema de lo causal y lo incondicionado. Como cifra de su escritura, este cuento trata de hallar la unidad de la vida múltiple, rasgo peculiar de la estética de Lezama, a través de constantes transgresiones. De ese mundo en perpetua metamorfosis, quisiera destacar este fragmento:

La esposa se desabrochó, esperando el regreso del herrero para hacer cama. Desnuda se acercó a la pierna de la res, la contempló, acariciándola con los ojos desde lejos. La pierna trasudó como una gota de sangre que vino a reventar contra su seno. No reventó, al golpe duro de la gota de sangre en el seno sintió deseos de oscurecer el cuarto antes de que regresase el herrero. Sintió miedo de verse el seno y miedo de ver al esposo.

Dentro de un texto caracterizado por la ramificación textual y la polivalencia semántica, la imagen fálica de «la pierna de la res», que alude sexualmente a la frustración de la mujer, es la que introduce la sorpresa, lo inesperado, creando, mediante la unidad contradictoria del oxímoron («acariciándola con los ojos desde lejos»), una suspensión de la escritura, llena de tensiones, que sólo al final logra reunificar los elementos dispersos. Porque lo que se produce a lo largo del cuento es un desplazamiento de lo carnal, representado por el cangrejo, a lo espiritual de la golondrina, cediendo ésta su lugar a la paloma, que trae un tiempo de salvación. Por otro lado, dentro de un texto en el que el nombre de esa mujer nunca se llega a conocer, la oscilación entre el cangrejo y la golondrina, lo telúrico y lo estelar, el círculo y la elipse, genera un discurso diseminado, de avances y retrocesos, donde lo femenino permanece como lo indeterminado. En el fondo, lo que hace «la pierna de la res», metáfora de la diseminación textual, es generar un discurso que está por realizarse, la posibilidad de

\footnotetext{
${ }^{7}$ En cuanto a la raíz cósmica de la casa, afirma Bachelard: «Toda gran imagen simple y reveladora es un estado de alma. La casa es, más aún que el paisaje, un estado de alma. Incluso reproducida en su aspecto exterior, dice una intimidad» (1965: 11). Respecto a la convergencia de la gravedad y la ligereza, véase el ensayo de Calvino (1994: 15-41).
} 
abolir la distancia entre la experiencia y el lenguaje, que en la escritura de Lezama coinciden por completo ${ }^{8}$.

En La diosa blanca (1948), libro que privilegiaba Lezama Lima, escribe Robert Graves: «No recuerdo poeta auténtico alguno, desde Homero en adelante, que no haya registrado independientemente su experiencia de ella». La invocación de la Diosa Blanca o Diosa Triple, del Cielo, la Tierra y el Infierno, se debe a que es una personificación de la mujer primitiva, asociada a la diosa lunar que crea y destruye, cuya blancura iniciática se relaciona con los ciclos de la muerte y la resurrección, de los que participan tanto la experiencia religiosa como la poética. En cada acto amoroso se restaura la tradición de la Diosa Blanca, que puede adoptar las máscaras de sacerdotisa, sibila o reina, para que, como «Madre de Toda Vida», sirva para metaforizar la escritura en su doble movimiento de ocultación y revelación. Quizá por eso, Ovidio, en el capítulo X de sus Fasti, aludiendo a Cardea, representación de la Diosa Blanca, dice: «Su poder consiste en abrir lo que está cerrado y en cerrar lo que está abierto». Lo que subyace bajo esta vieja fórmula religiosa es el deseo de resolver la tensión entre lo oculto y lo manifiesto, propia de la escritura poética, relacionar el deseo de la madre y la escritura. Considerando a ésta más como estado que como acto, pues la espera de la mujer mantiene una visible analogía con la disponibilidad de la escucha o recepción, su hábito es erótico, porque se funda en la diferencia y va en contra de la identidad, rechazando la imposición de la máscara. Para Lezama, siguiendo en esto al historiador francés Michelet, el movimiento ideal del amor no es de penetración, sino de mediación entre la Naturaleza y el hombre. Mediante la alteridad profunda de la mujer, que exige el reconocimiento del mito de la antigua diosa o tierra madre, de las fuerzas primarias del instinto y la sexualidad, que había separado la tradición cristiana, el hombre puede alcanzar un conocimiento superior, al que se llega a través de la iniciación del ser en el mundo, que es el reino de lo femenino. Si partimos de que lo masculino y lo femenino, el animus y el anima, son por naturaleza fuerzas opuestas y complementarias, sombra-luz, espíritu-materia, activo-pasivo, su unificación será necesaria para una relación con la realidad primordial. De ahí que en la escritura de Lezama, cuyo movimiento es más circular que lineal, lo erótico lo envuelve todo y representa la unidad a la que aspira todo ser que está separado. No es otra la función de la poesía, que, en su deseo de rescatar la forma originaria, muere y renace, vive en un estado de sacrificio, como intermediaria entre el reino de la oscuridad y el de la luz'.

La vida de Lezama Lima transcurrió en un ambiente femenino, regido por mujeres, que se hicieron cargo de la situación familiar y favorecieron su disposición a recibir en el estado de creación.

\footnotetext{
${ }^{8}$ Sobre el oxímoron, escribe Certeau: «Es un deíctico: muestra lo que no dice. La combinación de los dos términos sustituye la existencia de un tercero y lo presenta como ausente. Es un lenguaje que tiende a un no-lenguaje» (1982: 174). En cuanto al análisis de este cuento, remito al ensayo Ulloa (1991: 77-89).

${ }^{9}$ En el texto «La espiral milagrosa», que aparece como prólogo a la edición española de Fragmentos a su imán escribe Goytisolo: «El mundo femenino, diseminado muchas veces y falseado otras, endosado normalmente en la historia a un segundo plano o con papeles de comparsería, salvo en algunas grandes obras, aparece siempre en Lezama envolviéndolo todo, como líquido amniótico que hace posible la vida, y sus personajes femeninos son preponderantes, tan reales como las mujeres que le acompañaron, a las que comprendió y por las que fue comprendido» (1978). En cuanto al mito de la antigua diosa, que dominó la tierra y el cielo antes de la aparición de las religiones patriarcales, remito al estudio de Whitmont (1998).
} 
En este sentido, la casa, lo propio donde se está, se convierte en el instante estético en el que lo múltiple recupera su unidad. Aquella morada o punto de reunión, la casa sellada de Trocadero 162, no sólo le sirvió de refugio frente a los vaivenes políticos, tan ajenos a su profesión, sino también para adentrarse en sí mismo («Entremos más adentro en la espesura», dice Juan de la Cruz en el Cantico espiritual), para mostrar, desde ese espacio de retracción íntima, una sistematización poética del mundo. En el primero de los «Cinco fragmentos para Antoni Tàpies», perteneciente a su libro de poemas Material memoria (1979), José Ángel Valente, tan afín al espíritu de Lezama, escribe: «Crear lleva el signo de la feminidad. No es acto de penetración en la materia, sino pasión de ser penetrado por ella». En ese estado de espera en el que vive la mujer, que es lo que da forma a lo que llega del otro lado, se forma la escritura poética, que habita el territorio de lo indeterminado, de lo incierto, donde no dejan de confundirse lo decible y lo indecible. En su recinto sagrado, la mujer, como objeto religioso, expresa esa ambigüedad: cero fecundo de la matriz. Si en las antiguas religiones las diosas llevaban nombres femeninos, Inanna en Sumeria, Anath en Canaán, Isthar en Mesopotamia, Sejmet en Egipto, Morrigan en Irlanda, Kali en la India, Palas en Grecia y Belona en Roma, es porque controlaban el ciclo de la vida y guiaban hacia la metamorfosis. De igual modo, la palabra poética, por surgir de lo profundo, participa de la visión transformadora de lo femenino, de su aspecto receptivo, capaz de alojar el sentimiento y la imaginación. La relación que Lezama mantiene en su escritura con lo femenino arquetípico, con la madre como protectora de vida, supone una vuelta a lo primigenio, pues como recuerda Lao Tse en el Tao Te King, «El espíritu de la fuente no muere nunca». Tal vez en ese doble juego de visiones arquetípicas y representaciones simbólicas encuentre la escritura de Lezama una nueva forma ritual de reconocimiento: la supervivencia de los impulsos primitivos en el territorio abismal de lo femenino.

\section{Bibliografía}

BACHELARD, G. (1965): La poética del espacio. México, FCE.

BARTHES, R. (1982): Fragmentos de un discurso amoroso. Madrid, Siglo XXI.

BAtAILle, G. (1982): El erotismo. Barcelona, Tusquets.

CALVINO, I. (1994): «Levedad», en Seis propuestas para el próximo milenio. Madrid, Siruela, pp. 15-41.

CERTEAU, Michel de (1982): La fábula mística. México, Iberoamericana.

LÉvinAS, E. (1977): Totalidad e Infinito. Salamanca, Sígueme.

LeZAMA Lima, J. (1975-1977): Obras completas. México, Aguilar, 2 Tomos. (1977): Oppiano Licario. México, Ediciones Era.

_ (1978): Fragmentos a su imán. Barcelona, Lumen.

MAtAmoro, B. (1987): «Oppiano Licario: seis modelos en busca de una síntesis», en E. SUÁREZGALBÁN, ed., Lezama Lima. Madrid, Taurus, pp. 197-212.

Murena, H.A. (1984): La metáfora y lo sagrado. Barcelona, Alfa.

NANCY, Jean-Luc (2003): Corpus. Madrid, Arena Libros. 
Ortega, J. (1969): «Paradiso», en La contemplación y la fiesta. Caracas, Monte Ávila, pp. 77-116.

RuIz BARRIONUEVO, C. (1984): «Enemigo rumor, de José Lezama Lima», Coloquio Internacional sobre la obra de José Lezama Lima. Madrid, Fundamentos, Vol. I, pp. 171-186.

SchubaRt, W. (1966): Religion und Eros. Múnich, Beck’sche, Verlag.

UlloA, Leonor A. de (1991): «Cangrejos, golondrinas: metástasis textual», Revista Iberoamericana, Vol. LVII, núm.154 (enero-marzo), pp. 77-89.

VALCÁRCEL, E. (1999): «La vivencia oblicua, fragmentos sobre una lectura de Lezama Lima», Anales de Literatura Hispanoamericana, 28, pp. 1255-1263.

WhitMont, Edward C. (1998): El retorno de la diosa. Barcelona, Paidós.

YURKIEVICH, S. (2002): «José Lezama Lima: el eros relacionable o la imagen omnímoda y omnívora», en Fundadores de la nueva poesía latinoamericana. Barcelona, Edhasa, pp. 407-425. 